\title{
Season and site fidelity determine home range of dispersing and resident juvenile Greenland cod Gadus ogac in a Newfoundland fjord
}

\author{
Melanie Shapiera ${ }^{1, *}$, Robert S. Gregory ${ }^{2}$, Corey J. Morris ${ }^{2}$, Curtis J. Pennell ${ }^{2}$, \\ Paul V. R. Snelgrove ${ }^{1}$ \\ ${ }^{1}$ Department of Biology and Ocean Sciences Centre, Memorial University of Newfoundland, St. John's, \\ Newfoundland A1C 5S7, Canada \\ ${ }^{2}$ Fisheries and Oceans Canada, Ecological Sciences Section, 80 East White Hills Road, PO Box 5667, St. John's,
} Newfoundland A1C 5X1, Canada

\begin{abstract}
We used acoustic telemetry to track age 1 juvenile Greenland cod Gadus ogac in Newman Sound, Newfoundland, from October 2010 to November 2012, in 2 consecutive 1 yr experiments. Using single (Year 1) and reciprocal (Year 2) transplant study designs, we investigated seasonal dispersal, home range area, and potential homing behaviour between coves $\sim 3.5 \mathrm{~km}$ apart. We tracked individuals moving at metre to kilometre scales, using a network of 26 to 32 hydrophones. We converted tag detections to position estimates in order to calculate seasonal home ranges and individual movement patterns. Home range increased significantly with season (pre-winter, winter, and post-winter) in both study years. Mean seasonal home range area ranged from 0.29 to $3.47 \mathrm{~km}^{2}$ in Year 1 and 0.43 to $1.72 \mathrm{~km}^{2}$ in Year 2. In contrast, fish size-at-capture, capture location, and release location had no significant effect on seasonal home range. Increased movement distance during the winter and post-winter season suggests a reduction in predation pressure on age 1 juveniles at these times, challenging previous assumptions about their vulnerability. We observed variable behaviour spanning residency to kilometre-scale dispersal movements, which represent greater distances than previously assumed. Similar proportions of control and transplant fish visited the other cove, indicating an absence of homing behaviour among dispersing individuals. Juveniles of marine fishes are often characterized as key life history transition stages between vulnerable larvae and older, larger individuals which are less susceptible to predators. Our results indicate that early juvenile life stages may be substantially more mobile than presupposed and contribute to population connectivity in temperate fishes in ways not well described previously.
\end{abstract}

KEY WORDS: Home range $\cdot$ Telemetry $\cdot$ Gadus ogac $\cdot$ Dispersal $\cdot$ Juvenile $\cdot$ Site fidelity

\section{INTRODUCTION}

In marine ecosystems, ontogenetic changes in dispersal behaviour are likely the norm, not the exception (e.g. Bishop et al. 2010, Di Franco et al. 2012). Effective management and conservation of populations require knowledge of population connectivity, including dispersal of larvae and home range areas of post-larval juvenile stages (Bradbury et al. 2008). Many challenges (e.g. insufficient marine reserve size for proper model evaluations, unknown spatial recruitment patterns) exist when producing such estimates (Halpern \& Warner 2003). However, mortality during dispersal, potential range of dispersal, 
and site fidelity collectively determine dispersal among individual post-larval marine fish, and all contribute to the resilience and stability of a given population. Hence, these estimates are critical to managers and for understanding population dynamics and connectivity.

Animal movement behaviours associated with foraging, predator avoidance, and reproduction, among other factors, can manifest themselves spatially in the form of a home range area (Burt 1943, Börger et al. 2008). Individuals confining their movements to a specific area impacts the ecology of a species or population, potentially shaping predator-prey dynamics (Lewis \& Murray 1993), habitat selection (Rhodes et al. 2005), and population regulation (Wang \& Grimm 2007). Familiarity with its home range often benefits an individual by increasing efficiency in feeding (Hughes \& Blight 2000) and avoidance of habitats with high predator density (Brown 2003). These benefits could be particularly important for vulnerable juveniles. However, individuals risk these benefits being offset by forsaking exploitation of higher quality habitats elsewhere (Kramer \& Chapman 1999). In aquatic ecosystems, demersal fish may invest more energy than pelagic fish in maintaining and familiarizing themselves with a home range because they interact closely with the seafloor substrate (Kramer \& Chapman 1999). Home range size and location may change with age class, individual state, and external environment. This variability has catalyzed the emergence of statistical modelling of home range area in order to address dynamic landscapes and conditions (Börger et al. 2008). In particular, estimating utilization distributions from probability density functions indicated by location data (Worton 1989) has become prominent.

Large inter-individual variation in movement and dispersal behaviour may be evident within populations. This contrast in behaviour could manifest itself in large versus small home range areas. Behaviour variations are common in temperate fishes and have been well studied in anadromous salmonids in particular. Focussing on juveniles, Chinook salmon Oncorhynchus tshawytscha exhibit both resident ('streamtype') and dispersing ('ocean-type') life histories (Taylor 1990), even within the same populations (Bradford \& Taylor 1997). Atlantic salmon Salmo salar juveniles also invoke both resident strategies characterized by small territories, and more mobile strategies to exploit new areas (Armstrong et al. 1997). The same pattern has been observed in Atlantic cod Gadus morhua: Adult individuals in Gilbert Bay, Labrador and age 2-3 juvenile cod in Newman
Sound, Newfoundland exhibit substantial variation in distances travelled from release sites (Green \& Wroblewski 2000, Cote et al. 2004). Specific populations of adult Atlantic cod have been characterised as resident, homing, or dispersing (Robichaud \& Rose 2004, Neat et al. 2006). Site fidelity or homing patterns can vary across life stages in response to increased opportunity for spatial or social learning, depending on habitat stability (Dodson 1988, Odling-Smee \& Braithwaite 2003) or body condition (Comeau et al. 2002). These varying patterns affect the contributions of movements of individual fishes to population connectivity. Young fish in particular are potentially vulnerable to predation and may benefit from resident (rather than dispersing) strategies that require and stimulate learning of shelter and feeding sites within their individual or group home range. Conversely, if transplanted to a new habitat, juveniles may benefit from homing strategies that allow them to return to areas with known shelter and feeding sites.

Determining home ranges for animals in marine environments is especially challenging, partly because of the open nature of their habitat and the spatially unrestricted opportunities for dispersal. Furthermore, technological limitations have seriously constrained past investigation into movements of individual juvenile temperate fishes. We have hitherto known little about dispersal potential and areal usage by young (age 1) marine fish. Young juveniles are often considered a transitional life-history stage between larvae and older, larger juveniles that are presumably less susceptible to most predators than their smaller conspecifics, and therefore considered more mobile. Moreover, data on temporal variation in home range across seasons and temperature are necessary for investigating the mechanisms affecting dispersal (Börger et al. 2008) to facilitate the conservation of species and their habitats.

Greenland cod Gadus ogac, a subspecies of Pacific cod Gadus macrocephalus (Coulson et al. 2006), spans Arctic and subarctic waters from Greenland south to Newfoundland and New England, and west to Alaska (Scott \& Scott 1988). Published accounts of the more extensively studied Atlantic cod describe movements of older individuals over both space and time through mark-recapture methods (Grant \& Brown 1998b, Laurel et al. 2004, Robichaud \& Rose 2004) and acoustic telemetry (Cote et al. 2004, Lindholm et al. 2007). At the juvenile stage, Greenland cod exhibit demersal habitat use and behaviour similar to juvenile Atlantic cod (e.g. Laurel et al. 2004) and are morphometrically similar until at least age 1 (Methven \& McGowan 1998). 
Age 2-3 juvenile Atlantic cod in Newfoundland alter their behaviour from the summer to autumn and winter periods, presumably in response to the disappearance of the shallow $(<30 \mathrm{~m})$ thermocline (Clark \& Green 1990, Cote et al. 2004). However, at age 0, both Atlantic and Greenland cod associate with complex habitats such as eelgrass, Zostera marina, as a refuge from predation (Laurel et al. 2003); consequently, age 0-1 Gadus spp. are thought to have more limited distributions, with movements restricted within home ranges of a few hundred to thousands of square metres (Tupper \& Boutilier 1995, Laurel et al. 2004). Furthermore, both juvenile Atlantic and Greenland cod can produce plasma antifreeze glycoproteins (Morin et al. 1991, Goddard et al. 1992) at levels double those seen in older conspecifics (Kao \& Fletcher 1988). These glycoproteins are an adaptation to overwintering environments (Goddard et al. 1999), potentially allowing age 1 juveniles to remain in cooler, shallower waters than their predators during the winter season.

Recent advances in acoustic telemetry technologyi.e. smaller tag size and increased battery life-facilitated our study of movement and spatiotemporal variation in home range size in a small-bodied $(<20 \mathrm{~cm}$ long) juvenile marine fish. We estimated the position of tagged individual age 1 (1 yr old) Greenland cod within a hydrophone array over a full year. We generated home range estimates for each individual during pre-winter, winter, and post-winter seasons to examine the effect of temperature and season on individual variation in home range size, site fidelity, and potential homing behaviour. We tagged and released juveniles from 2 locations ( $3.5 \mathrm{~km}$ apart) in a controlled-transplant experiment (Year 1) and a reciprocal controlled-transplant experiment (Year 2) design. In each of the 2 study years, we simultaneously tracked 42 tagged age 1 Greenland cod along more than $32 \mathrm{~km}$ of coastline (total 84 ind.). The spatial scale and timeframe of our study increase our understanding of the movement potential and realized dispersal of a poorly studied life stage of fish, and allow inferences on an important transition period in the life-history of many coastal marine fishes.

\section{MATERIALS AND METHODS}

\section{Study area}

Newman Sound is a $41 \mathrm{~km}$ long and 1.5 to $3 \mathrm{~km}$ wide fjord located in Bonavista Bay, Newfoundland, Canada (Fig. 1), adjacent to Terra Nova National

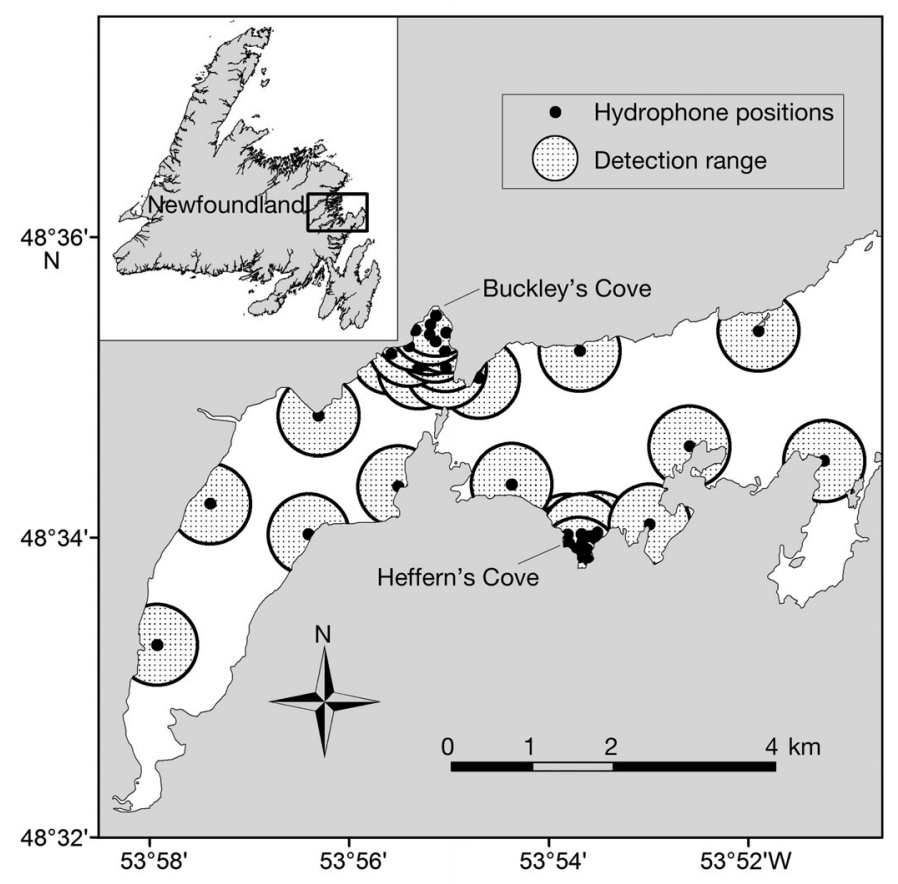

Fig. 1. Positions and $500 \mathrm{~m}$ detection radii of the VR2/VR2W hydrophones deployed in Newman Sound, Newfoundland, Canada, between October 2010 and November 2011

Park. The area was selected for reasons of logistical support and detailed a priori knowledge from related field research in the area. The sound consists of an inner and outer basin, with maximum depths of $55 \mathrm{~m}$ and $>300 \mathrm{~m}$, respectively. The 2 basins are divided by a sill that rises to a depth of $18 \mathrm{~m}$. In our study area, eelgrass grows subtidally to depths of $\sim 6 \mathrm{~m}$ and dominates areas of the southern shore of the sound, such as Heffern's Cove (HC, Fig. 1) in the outer basin and Buckley's Cove (BC, Fig. 1) on the northern shore of the inner basin. Mini-T-II (Vemco, accuracy of $\pm 0.01^{\circ} \mathrm{C}$ from $-5^{\circ}$ to $35^{\circ} \mathrm{C}$ ) temperature loggers (placed $0.5 \mathrm{~m}$ above the sea floor) recorded ambient water temperatures at our 2 study sites hourly; mean daily water temperatures ranged from lows of -0.3 and $-0.6^{\circ} \mathrm{C}$ during mid-February in 2011 and 2012, respectively, to highs of 15.3 and $17.4^{\circ} \mathrm{C}$ in August 2011 and 2012, respectively (Fig. 2).

\section{Acoustic receivers}

In 2010, we deployed 12 acoustic monitoring receivers (Vemco VR2W, $69 \mathrm{kHz}$ receiving frequency) within $\mathrm{HC}$, and an additional 14 Vemco VR2 receivers (69 $\mathrm{kHz}$ receiving frequency) throughout Newman Sound (Fig. 1). All receivers had a tag detection radius of ca. $500 \mathrm{~m}$ (Fig. 1; determined from 


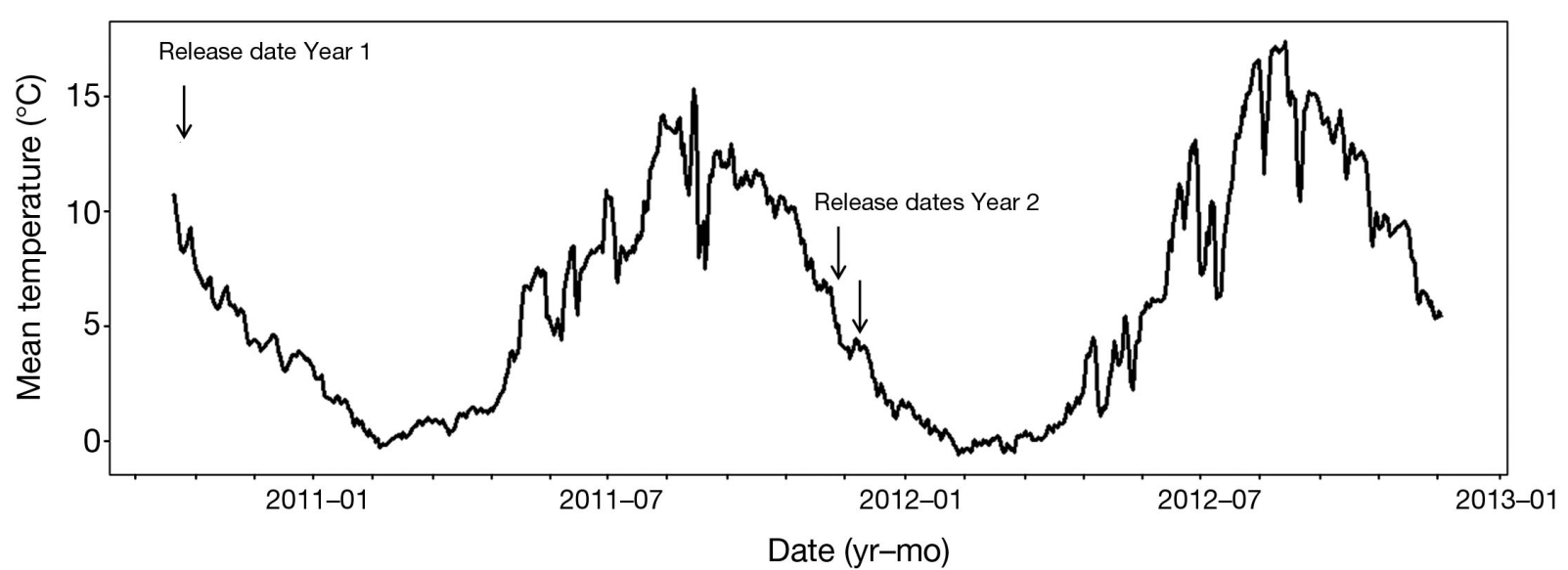

Fig. 2. Mean daily water temperature of Newman Sound as determined from 4 coastal temperature loggers. Year 1 (2010-2011) and Year 2 (2011-2012) Greenland cod release dates are indicated by arrows

in situ range tests), and were positioned $1 \mathrm{~m}$ off the seafloor to optimize detection of cod carrying acoustic tags. In November 2011, we deployed 6 additional VR2W receivers in $\mathrm{BC}$ to achieve higher resolution during the second year of our study. All acoustic receivers were retrieved every 6 to $7 \mathrm{mo}$ and the data downloaded from each receiver to a laptop computer. We then redeployed acoustic receivers to their original positions.

All tagged fish were captured and released in either $\mathrm{HC}$ or $\mathrm{BC}$. Receivers in these 2 coves were positioned to provide overlapping coverage, facilitating high spatial resolution $(\sim 5 \mathrm{~m})$ position estimates. Receivers outside these sites allowed coarser spatial resolution $(\sim 0.5 \mathrm{~km})$ position estimates over a larger area, to detect any acoustically tagged individuals that left either of the 2 release sites.

\section{Acoustic tags}

In total, we captured 42 age 1 Greenland cod from $\mathrm{BC}$ or $\mathrm{HC}$ by beach seine in each study year (October 2010 and November 2011). Vemco V7-4L coded acoustic tags (nominal life $415 \mathrm{~d}$ ) were programmed to emit a signal every $240 \mathrm{~s}$, with a randomized delay of $\pm 70 \mathrm{~s}$. A tag was surgically implanted in each fish through a small $(\sim 1 \mathrm{~cm})$ incision made off centre of the belly midline, which we then stitched closed with 2 sutures during each $\sim 30 \mathrm{~s}$, non-anaesthetized procedure. Tagged individuals were allowed to recover overnight (October 2010) or over a period of $1 \mathrm{~h}$ (November 2011) in a net pen prior to release.

The study consisted of 2 separate experiments: a single transplant from BC to HC on 8 October 2010, and a reciprocal transplant between the 2 coves on 9 and 23 November 2011 (see Table 1). In 2010, we captured 21 fish from $\mathrm{HC}$ and $\mathrm{BC}$ each and released all 42 tagged fish in HC (i.e. 21 treatment and 21 control individuals, mean standard length $\pm \mathrm{SD}=16.3 \pm$ $0.9 \mathrm{~cm}$ ). These fish were tracked from release until November 2011. In 2011, we captured 28 fish from $\mathrm{BC}$ and 14 from $\mathrm{HC}$, releasing half of the fish in their cove of origin, and half in the other cove (see Table 1 ; total $=42 \mathrm{cod}$, mean standard length $=17.2 \pm 1.3 \mathrm{~cm}$ ). These fish were tracked from release until 14 November 2012.

\section{Data analyses}

We eliminated spurious detections (e.g. lone detection over $24 \mathrm{~h}$ for an individual fish), consistent with common practice (March et al. 2010, Alós et al. 2011). Passive acoustic telemetry networks, though less labour-intensive than active tracking, only provide positions of individual transmitters within the omnidirectional range of detection of the hydrophones in the network ( $500 \mathrm{~m}$ in our study). Using the plyr package in R software (Wickham 2011), we calculated position estimates in hourly time intervals using a weighted arithmetic mean based on known hydrophone positions to increase precision from a presence/absence dataset to a position-based dataset (Simpfendorfer et al. 2002). For each year, we then used ArcGIS and the adehabitatHR package (Calenge 2006) in $\mathrm{R}$ to calculate mean seasonal $95 \%$ kernel utilization distribution (KUD), standardized using a Monte Carlo approach (see Farrugia et al. 2011). We considered position estimates up until $1 \mathrm{yr}$ after the release date for home range analyses. 
We estimated the seasonal home ranges for each year separately using generalized linear models (GLM) in $\mathrm{R}$ software. The winter season was defined as having average coastal ( $\sim \mathrm{m}$ depth) water temperatures $4^{\circ} \mathrm{C}$ or lower. All temperature loggers were placed in coastal areas with a water depth of $\sim 3 \mathrm{~m}$. The loggers themselves were placed $0.5 \mathrm{~m}$ above the sea floor ( December to April), to coincide with the breakdown of the thermocline in autumn. We defined our pre-winter and post-winter seasons by their average water temperatures $\left(>4^{\circ} \mathrm{C}\right)$ and a generally declining temperature in pre-winter, in contrast with a rising temperature in post-winter. Tagged individuals were presupposed to exhibit potential behaviour differences over time as they aged and presumably increased in size from pre-winter to post-winter seasons. We examined effects of transplant status ('transplant': cove of release $\neq$ cove of capture vs. 'control': cove of release $=$ cove of capture) and season on home range size in 2010-11 using a 2-way ANOVA. In addition to these variables, we also examined the effect of cove of capture on home range size in 2011-12 using a 3-way ANOVA. For each ANOVA, the unbalanced design required Type II SS analysis. Our data were not normally distributed; therefore, we validated our ANOVA results using randomization tests for each year (1000 iterations of the ANOVA F-statistics following randomization, considering $\mathrm{p} \leq 0.05$ statistically significant).

We categorized fish based on movement distance and location into 3 groups: 'resident', those individuals remaining in the cove of release; 'visitors', those moving to the other cove; and 'travellers', those moving elsewhere. We use the term 'dispersers' when referring to both visitors and travellers. We investigated potential differences in initial standard length between resident and dispersing fish using a 2-sample $t$-test for both years separately. To investigate potential differences in behaviours among experimental groups, we used a Pearson's chi-square test separately for each experiment. In the Year 1 single transplant experiment, we evaluated the response variable behaviour (3 levels: resident, disperser visitors, and disperser travellers) across 2 treatment groups (control and transplant). In the Year 2 reciprocal transplant, we compared the same 3 behaviour variable levels among 4 treatment groups (BC control, BC transplant, HC control, and HC transplant, named first based on their cove of origin and then transplant status). The null hypothesis for each test was that proportions of behaviours across all treatment groups are equal, i.e. that behaviours are independent of treatment. As a result of low detection and early mortality, some treatment groups included $<5$ fish, and results were therefore evaluated further using a randomization test for each year (1000 iterations of the chi-square test following randomization, with $\mathrm{p} \leq 0.05$ considered statistically significant). A separate chi-square analysis for Year 2 pooled the fish into only transplant and control groups. We also examined detection data time series for 'visitor' fish to determine the path of travel to the other cove.

\section{RESULTS}

\section{Acoustic tracking}

Our receiver array detected 41 of the 42 tagged individuals in each of the $2 \mathrm{yr}$ (Table 1) for periods ranging from 25 to $399 \mathrm{~d}$ in Year 1 (8 October 2010 to 8 November 2011) and 4 to $369 \mathrm{~d}$ in Year 2 (9 November 2011 to 14 November 2012). The majority of fish were detected for $<125$ and $<150 \mathrm{~d}$ in Year 1 and 2, respectively (Fig. 3). Clustering of position estimates for $6 \mathrm{cod}$ in Year 1 and $1 \mathrm{cod}$ in Year 2 within a 28 to $40 \mathrm{~m}$ radius for their entire respective studies suggests mortality of these particular individuals during the first month at large, although the tagged individuals did move during the first $\sim 3 \mathrm{wk}$ following

Table 1. Summary of detection data for the Year 1 (2010-2011) and Year 2 (2011-2012) tagging seasons. HC = Heffern's Cove, $\mathrm{BC}=$ Buckley's Cove

\begin{tabular}{|c|c|c|c|c|c|c|}
\hline Release date & $\begin{array}{l}\text { Cove of } \\
\text { capture }\end{array}$ & $\begin{array}{l}\text { Cove of } \\
\text { release }\end{array}$ & $\begin{array}{l}\text { Total no. of } \\
\text { fish tagged }\end{array}$ & $\begin{array}{l}\text { Total no. of } \\
\text { fish detected }\end{array}$ & $\begin{array}{l}\text { Tracking period } \\
\text { range (d) }\end{array}$ & $\begin{array}{l}\text { Average standard } \\
\text { length } \pm \mathrm{SD}(\mathrm{cm})\end{array}$ \\
\hline \multirow[t]{2}{*}{ Oct 82010} & $\mathrm{HC}$ & $\mathrm{HC}$ & 21 & 21 & $25-399$ & $15.9 \pm 0.7$ \\
\hline & $\mathrm{BC}$ & $\mathrm{HC}$ & 21 & 20 & $25-391$ & $16.8 \pm 0.9$ \\
\hline \multirow[t]{4}{*}{ Nov 92011} & $\mathrm{BC}$ & $\mathrm{BC}$ & 7 & 7 & $20-369$ & $16.8 \pm 1.6$ \\
\hline & $\mathrm{BC}$ & $\mathrm{HC}$ & 7 & 7 & $10-354$ & $17.1 \pm 0.8$ \\
\hline & $\mathrm{HC}$ & $\mathrm{HC}$ & 7 & 7 & 4-369 & $18.1 \pm 1.2$ \\
\hline & $\mathrm{HC}$ & $\mathrm{BC}$ & 7 & 6 & $47-203$ & $16.9 \pm 1.6$ \\
\hline \multirow[t]{2}{*}{ Nov 232011} & $\mathrm{BC}$ & $\mathrm{BC}$ & 7 & 7 & $26-356$ & $17.1 \pm 0.8$ \\
\hline & $\mathrm{BC}$ & $\mathrm{HC}$ & 7 & 7 & $43-356$ & $17.3 \pm 1.4$ \\
\hline
\end{tabular}




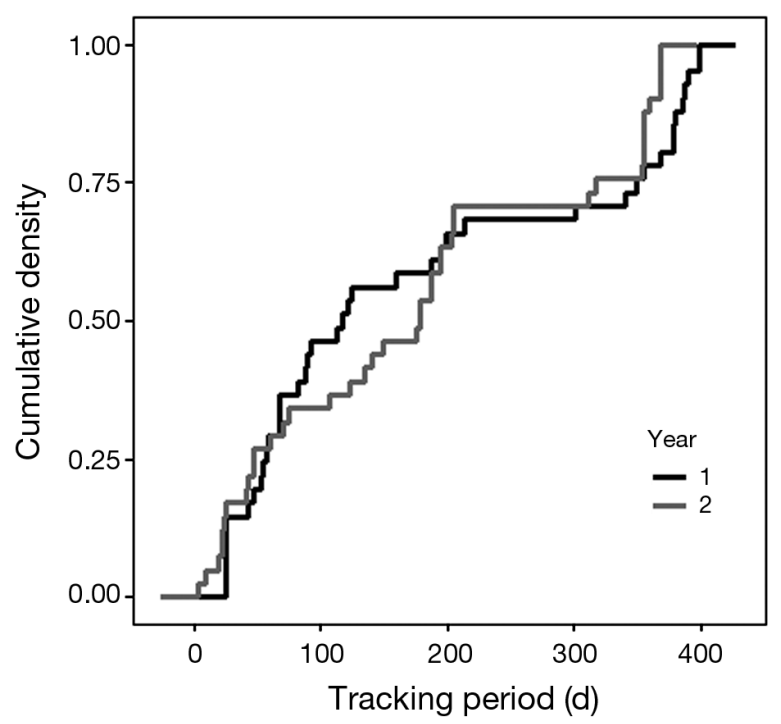

Fig. 3. Cumulative density of the tracking periods of individual Greenland cod detected during Year 1 (2010-2011) and Year 2 (2011-2012) tagging season

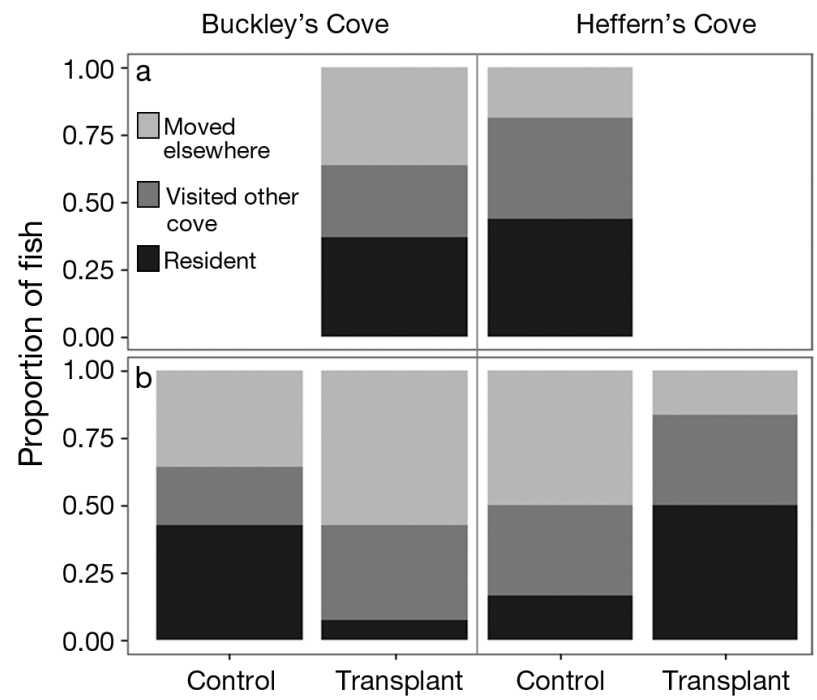

Fig. 4. Movement patterns exhibited by tagged Greenland cod in (a) Year 1 (2010-2011) and (b) Year 2 (2011-2012). Cod were caught in Buckley's Cove or Heffern's Cove and either transplanted to the other cove (transplant) or released in their cove of capture (control)

release. Accordingly, the acoustic tracking summary and the home range analyses used only the first month of position estimates for these individuals, and they were omitted from the chi-square analyses.

\section{Movement patterns}

Residents (i.e. fish remaining within their cove of release) comprised $40 \%$ of all tagged fish in Year 1 and $28 \%$ in Year 2 (Fig. 4). We found no significant differences in size-at-release between resident and dispersing fish in Year $1\left(t_{33}=-0.037, \mathrm{p}=0.97, \mathrm{n}=35\right)$ or in Year $2\left(t_{37}=1.08, p=0.29, n=39\right)$. Proportions of fish exhibiting the specific movement behaviours (residency, visiting the other cove, or travelling elsewhere) were independent of treatment groups in both Year $1\left(\chi^{2}=1.44, \mathrm{df}=2, \mathrm{p}=0.49, \mathrm{n}=35\right)$ and Year $2\left(\chi^{2}=7.09, \mathrm{df}=6, \mathrm{p}=0.31, \mathrm{n}=40\right)$. Randomization tests confirmed these results (1000 iterations each; Year 1: $p=0.428$; Year 2: $p=0.320$ ). No significant differences in behaviour proportions between treatment groups were found when fish in Year 2 were pooled into transplant status groups $\left(\chi^{2}=1.21\right.$, $\mathrm{df}=2, \mathrm{p}=0.55, \mathrm{n}=40$ ), a finding we again confirmed using randomizations $(\mathrm{p}=0.600)$.

The routes of 'visitor' fish indicated that the majority of individuals $(\sim 73 \%$ in Year $1,75 \%$ in Year 2$)$ travelled across the sill between the outer and inner basin to reach the other cove rather than following less direct routes along the shore. However, though some control and transplant individuals visited the other cove, few remained in either cove once reaching that site. In fact, no individuals from Year 1 remained in the other cove once they reached it; rather, they continued dispersing elsewhere $(\mathrm{N}=8)$ or returned to their initial cove of release $(\mathrm{N}=3)$. Both control $(\mathrm{N}=6)$ and transplant fish $(\mathrm{N}=5)$ continued dispersing after reaching the other cove. In Year 2, 5 fish (2 BC transplants, 1 BC control, 1 HC transplant, $1 \mathrm{HC}$ control) were last detected at the other cove, though 3 disappeared from the array for long periods of time. But other fish continued dispersing elsewhere $(\mathrm{N}=3: 1 \mathrm{HC}$ transplant, $1 \mathrm{BC}$ transplant, $1 \mathrm{BC}$ control), or returned to their release site $(\mathrm{N}=3$ : $1 \mathrm{BC}$ transplant, $1 \mathrm{BC}$ control, $1 \mathrm{HC}$ control). One fish (BC transplant) visited the other cove ( $\mathrm{HC})$, returned to its release site $(\mathrm{BC})$, then returned again to the other cove (HC).

\section{Home range}

We estimated average home range across seasons using a Monte Carlo standardized 95\% KUD (Table 2, Figs. 5 \& 6), whenever sufficient positions $(\mathrm{N} \geq 100)$ were obtained for each individual. In Year 1 , the pre-winter mean home range of individuals was $0.295 \mathrm{~km}^{2}$ (range of individual mean seasonal home range size $0.010 \pm 0.002$ to $3.705 \pm 1.395 \mathrm{~km}^{2}$ ). In winter, mean home range increased in area by 5 times to $1.455 \mathrm{~km}^{2}$ (range $0.017 \pm 0.006 \mathrm{~km}^{2}$ to $14.619 \pm 0.392 \mathrm{~km}^{2}$ ). After winter, mean home range 
Table 2. Average seasonal 95\% kernel utilization distribution (KUD) home range areas for each experimental group in the Year 1 (2010-2011) and Year 2 (2011-2012) experiments. HC = Heffern's Cove, BC = Buckley's Cove. Seasonal sample sizes are indicated for each group. nd: no data

\begin{tabular}{|c|c|c|c|c|c|c|}
\hline Year & $\begin{array}{l}\text { Cove of } \\
\text { capture }\end{array}$ & $\begin{array}{l}\text { Cove of } \\
\text { release }\end{array}$ & $\begin{array}{l}\text { Experimental } \\
\text { treatment }\end{array}$ & $\begin{array}{c}\text { Average pre-winter } \\
\text { home range }\left(\mathrm{km}^{2} \pm \mathrm{SD}\right)\end{array}$ & $\begin{array}{c}\text { Average winter } \\
\text { home range }\left(\mathrm{km}^{2} \pm \mathrm{SD}\right)\end{array}$ & $\begin{array}{c}\text { Average post-winter } \\
\text { home range }\left(\mathrm{km}^{2} \pm \mathrm{SD}\right)\end{array}$ \\
\hline 1 & $\mathrm{HC}$ & $\mathrm{HC}$ & Control & $0.35 \pm 0.90(\mathrm{~N}=19)$ & $1.99 \pm 5.10(\mathrm{~N}=8)$ & $2.94 \pm 3.10(\mathrm{~N}=4)$ \\
\hline 1 & $\mathrm{BC}$ & $\mathrm{HC}$ & Transplant & $0.23 \pm 0.38(\mathrm{~N}=17)$ & $0.92 \pm 1.48(\mathrm{~N}=8)$ & $4.00 \pm 4.21(\mathrm{~N}=3)$ \\
\hline 2 & $\mathrm{HC}$ & $\mathrm{HC}$ & Control & $0.11 \pm 0.16(\mathrm{~N}=6)$ & $0.05(\mathrm{~N}=1)$ & $0.50 \pm 0.21(\mathrm{~N}=2)$ \\
\hline 2 & $\mathrm{HC}$ & $\mathrm{BC}$ & Transplant & $1.18 \pm 2.51(\mathrm{~N}=6)$ & $0.42 \pm 0.62(\mathrm{~N}=3)$ & nd \\
\hline 2 & $\mathrm{BC}$ & $\mathrm{BC}$ & Control & $0.11 \pm 0.21(\mathrm{~N}=13)$ & $1.43 \pm 2.35(\mathrm{~N}=11)$ & $2.00 \pm 2.76(\mathrm{~N}=3)$ \\
\hline 2 & $\mathrm{BC}$ & $\mathrm{HC}$ & Transplant & $0.30 \pm 0.29(\mathrm{~N}=12)$ & $1.20 \pm 2.19(\mathrm{~N}=9)$ & $2.65 \pm 3.73(\mathrm{~N}=2)$ \\
\hline
\end{tabular}

(a) Year 1

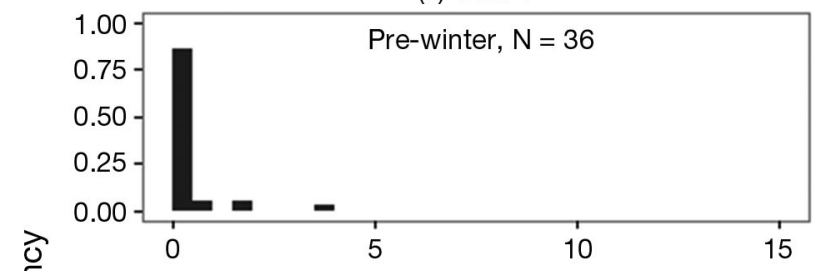

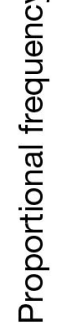

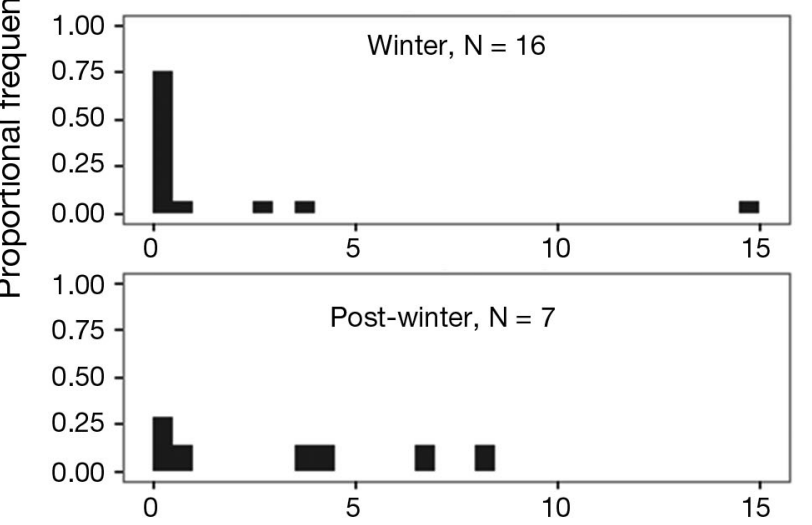

(b) Year 2
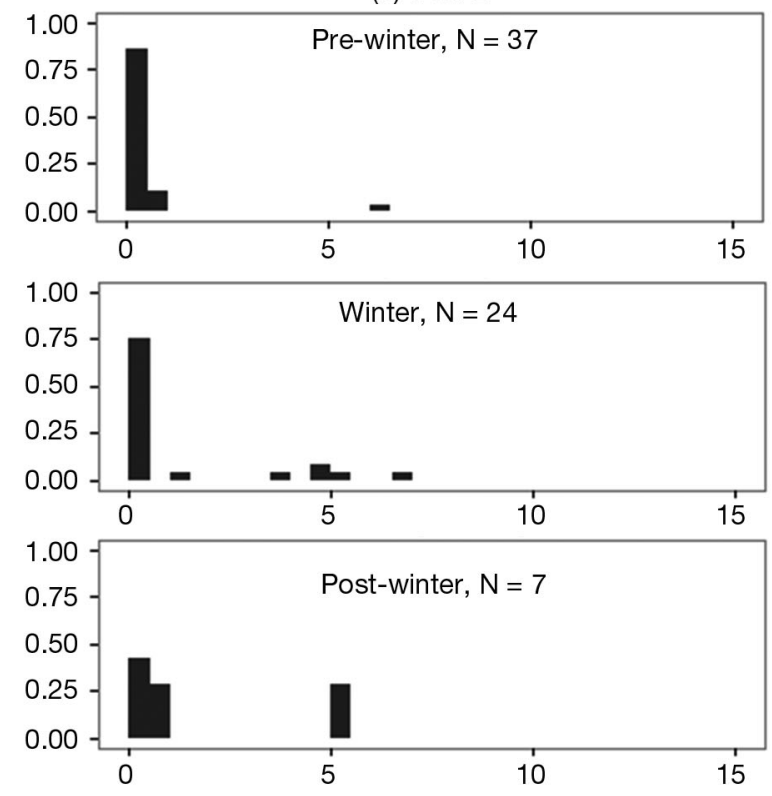

95\% Home range area $\left(\mathrm{km}^{2}\right)$

Fig. 5. Proportional frequency distributions of seasonal home ranges for (a) Year 1 (2010-2011) and (b) Year 2 (2011-2012) tagging season

was $3.392 \mathrm{~km}^{2}$ (range $0.036 \pm 0.007 \mathrm{~km}^{2}$ to $8.425 \pm$ $1.502 \mathrm{~km}^{2}$ ), over 11 times larger than pre-winter. The home range size of transplanted individuals was not significantly different from control fish released back into their area of capture (ANOVA, $F_{1,57}=0.165, \mathrm{p}=$ $0.687)$. There was no significant cove $\times$ season interaction $\left(F_{2,56}=0.552, \mathrm{p}=0.579\right)$, but season significantly affected home range area $\left(F_{2,56}=5.793, \mathrm{p}=\right.$ $0.005)$; randomization tests (1000 iterations) confirmed the significant season effect $(p=0.015)$. Home range size generally increased over time (Figs. 5a \& $6 a)$. Individual variation in seasonal home range size was substantial for the 6 fish whose home range could be calculated in all 3 of the seasons (Fig. 7a).

In Year 2, the mean pre-winter home range of $0.420 \mathrm{~km}^{2}$ (range $0.005 \pm 0.002$ to $6.303 \pm 0.336 \mathrm{~km}^{2}$ ) increased over 2.7 times in winter (mean $=1.161 \mathrm{~km}^{2}$, range $0.013 \pm 0.002$ to $6.610 \pm 0.285 \mathrm{~km}^{2}$ ). Mean postwinter home ranges were over 4.1 times higher than the pre-winter period at $1.759 \mathrm{~km}^{2}$ (range $0.012 \pm$ 0.001 to $5.283 \pm 0.374 \mathrm{~km}^{2}$ ). Although post-winter home range calculations were possible for 14 fish, only 7 extended past the month of May (these 7 were the only tagged cod for which we calculated home range, in order to avoid biasing our data analysis for early detections in May). We observed a significant season effect on home range area in Year 2, with larger later season home ranges on average than in pre-winter (ANOVA, $F_{2,65}=3.211, \mathrm{p}=0.048$ ), but no significant effects of cove of origin $\left(F_{1,66}=0.048, \mathrm{p}=\right.$ $0.827)$, transplant status $\left(F_{1,66}=0.418, \mathrm{p}=0.521\right)$, cove $\times$ transplant status interaction $\left(F_{1,66}=0.639, \mathrm{p}=\right.$ 


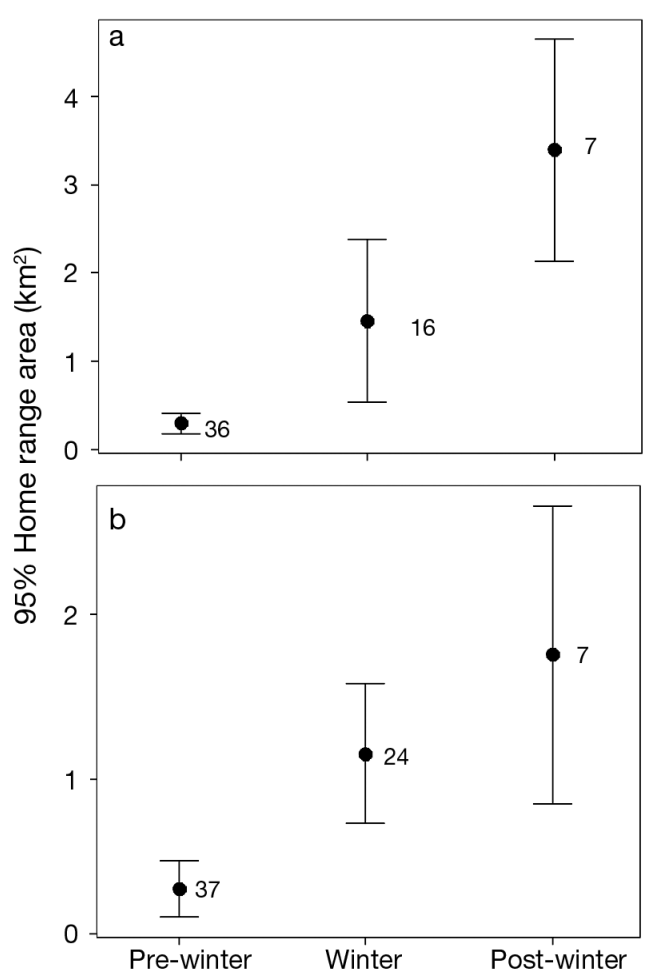

Fig. 6. Seasonal mean ( $\pm \mathrm{SE}$ ) home ranges for (a) Year 1 (2010-2011) and (b) Year 2 (2011-2012) tagging season

$0.427)$, cove $\times$ season interaction $\left(F_{2,65}=1.268\right.$, $\mathrm{p}=$ $0.289)$, transplant status $\times$ season interaction $\left(F_{2,65}=\right.$ $0.216, \mathrm{p}=0.806)$, and cove $\times$ transplant status $\times$ season interaction $\left(F_{1,66}=0.014, \mathrm{p}=907\right)$. Randomization tests (1000 iterations) confirmed the significant season effect $(p=0.045)$ in our data. Home range size generally increased with time (Figs. 5b \& 6b). Individual variation in seasonal home range size was substantial for the 4 fish whose home range could be calculated in all 3 of the seasons (Fig. 7b). We observed no significant effect of size-at-release on seasonal home range size in either year of the study (Table 3).

Table 3. Summary of regression results examining effect of size-at-release on seasonal home range size for each experimental year. p-values are linked to the $t$-statistics

\begin{tabular}{|lcrrc|}
\hline Season & $\mathrm{r}^{2}$ & $t$ & $\mathrm{df}$ & $\mathrm{p}$ \\
\hline Year 1 & & & & \\
Pre-winter & 0.025 & -0.932 & 34 & 0.358 \\
Winter & 0.046 & -0.825 & 14 & 0.423 \\
Post-winter & 0.036 & 0.434 & 5 & 0.682 \\
Year 2 & & & & \\
Pre-winter & 0.009 & 0.577 & 35 & 0.568 \\
Winter & 0.004 & 0.299 & 22 & 0.768 \\
Post-winter & 0.082 & 0.287 & 5 & 0.789 \\
\hline
\end{tabular}
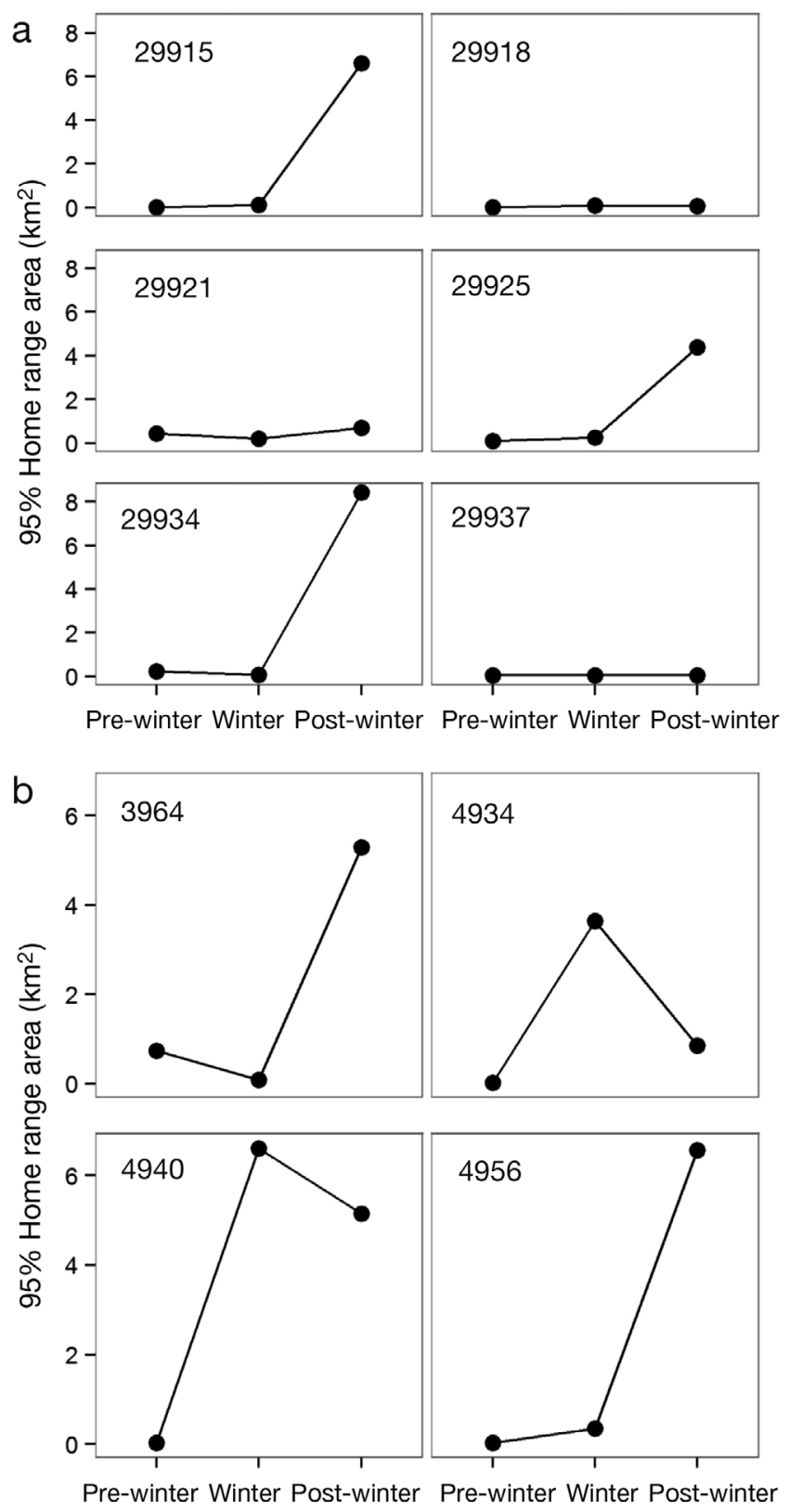

Fig. 7. Home range areas of individual fish with sufficient numbers of positions for all 3 season calculations. (a) Year 1 (2010-2011) and (b) Year 2 (2011-2012) tagging seasons.

Tag IDs are indicated in each panel

\section{DISCUSSION}

The behavioural ecologies of most juvenile life stages of marine and estuarine fishes are not well understood. For commercially managed species, our knowledge of the dispersal and behaviour of juvenile forms is typically poor compared to that of their better studied adult forms. Our study demonstrated much greater movement of age 1 Greenland cod than 
previously thought, particularly in winter and postwinter seasons, indicating a greater contribution to population connectivity than presumed.

In this study, we used acoustic telemetry technology to determine spatiotemporal variation in home range size of a poorly studied life stage of fish, and we discovered that many age 1 Greenland cod dispersed on kilometre scales. Dispersal potential among individuals was much larger than we had expected, based on the previously documented behaviour of smaller, younger individuals (Tupper \& Boutilier 1995, Grant \& Brown 1998b, Laurel et al. 2004) as well as older ones (Clark \& Green 1990, Cote et al. 2004). However, we observed wide variation in behaviour, with some fish remaining in their cove of release for the entire tagging period ('residents'), and others moving to other areas ('dispersers').

Our home range estimates also reflect this behaviour variation, particularly in the winter and postwinter seasonal home range area distributions. Typically, home range studies focus on species or life stages that consistently reside within a specific area, or those with relatively small home ranges. In their review of home ranges, Kramer \& Chapman (1999) suggested that fish may limit their activity to a home range in order to increase efficiency in resource use, particularly for feeding and refuge sites, through behaviour learned over an individual's life. Certainly, some adult Atlantic cod populations are relatively sedentary residents of the coastal zone (Robichaud \& Rose 2004, Neat et al. 2006), and young juvenile Atlantic cod generally occur in shallow coastal environments (Anderson \& Gregory 2000), suggesting specific home range area use. In our study, however, home range areas spanned hectares to square kilometres and showed a dichotomy between individuals that were relatively sedentary residents and those that dispersed. This dichotomy was independent of either the site of initial capture or site of release. Home ranges $>1 \mathrm{~km}^{2}$ were equally likely in both control and transplant fish in both years of our study. Our study may have underrepresented the occurrence of larger home ranges in this population because of more limited receiver coverage at greater distances from the release points of our tagged fish. Assuming that some fish with large home ranges were indeed missed, our inferences would actually be stronger if these fish had been detected and included in our analyses. The larger home ranges of dispersing individuals suggest some degree of 'motivation' to leave areas that are presumed to afford greater cover from predators. Indeed, mean seasonal home range areas during both our tagging periods exceeded those documented for age 2 Atlantic cod (Cote et al. 2004). However, substantial variation in seasonal home range area was evident among individuals detected during all 3 seasons in our study. In both years, 3 categories emerged: (1) fish with consistently small home range areas across seasons (2) fish with small pre-winter and winter home range areas followed by a large increase in home range area post-winter, and (3) fish with home range areas that increased to the largest size during the winter season and then retracted slightly in the post-winter season. For gadids, we suggest that age 1 represents a transition point in their early life history where individuals become less associated with complex habitat than smaller age 0 cod (e.g. Thistle et al. 2010), but exhibit a less defined home range than larger age 2-3 cod (Cote et al. 2004). Of our 3 initial potential influences on home range area (season, site of capture, site of release), only season had a significant effect. Mean home range size increased significantly over time, even in winter. However, sites of capture or release did not significantly affect results.

Predation is a major structuring force in marine communities, particularly for juvenile fish, affecting individual decisions on when, where, what, and even how to eat (Lima \& Dill 1990). Young cod are potential prey for piscivorous fish, such as short-horned sculpin Myoxocephalus scorpius, and older, larger conspecifics (Bogstad et al. 1994, Linehan et al. 2001), as well as mammals (Cote et al. 2008). Therefore, age 0 cod are presumed to select shallow coastal waters to reduce predation risk (Linehan et al. 2001) by limiting encounter rates with these predators (Gotceitas et al. 1997, Grant \& Brown 1998b). This anti-predator behaviour confines their movements to within a few hundred metres from protective habitat (Tupper \& Boutilier 1995, Grant \& Brown 1998b, Laurel et al. 2004, Schneider et al. 2008). However, among the early life stages of fish, predation risk generally declines (Miller et al. 1988, Paradis et al. 1996), and vigilance to predators becomes less costly metabolically (Lima \& Dill 1990) as individuals grow. Therefore, cod may be more willing to explore open, previously more dangerous areas (Cote et al. 2003) as they grow. Diel distribution studies support such a behavioural explanation. Young Atlantic cod juveniles occur further from shore during the day, moving shoreward at night to feed (Clark \& Green 1990, Grant \& Brown 1998a,b). Greenland cod likely follow a similar pattern, occupying greater home ranges as they get older and larger.

Individual cod in our study would have encountered a wide range of temperature conditions, potentially affecting their behaviour and movement over time. For instance, home range increased in winter, 
compared to pre-winter distributions in both years. The thermocline typically breaks down between October and early November along the northeast Newfoundland coast (e.g. Colbourne 2004). This period correlates with changes in the distribution of several fishes, including cod, and their predators in our study area (e.g. Cote et al. 2003, 2008), many of which move to deeper water to avoid sub-zero temperatures and ice crystals (Goddard et al. 1992). Changes in ice distribution, presence of super-cooled water, and sudden autumn temperature drops are known to kill both adult (Hoag 2003) and juvenile cod (R. S. Gregory unpubl. data). Similar seasonal movements to deep water have been observed in Atlantic cod (Hanson 1996, Comeau et al. 2002, Cote et al. 2004, Espeland et al. 2010). Importantly, however, plasma antifreeze levels in juvenile cod are significantly higher than in adults during winter conditions (Kao \& Fletcher 1988, Goddard et al. 1992). Consequently, when larger predators leave the area for warmer, deeper waters, age 1 juveniles likely can exploit the newly vacated areas that were previously dangerous for them in the pre-winter season. A reduction in predation pressure may account for the larger age 1 Greenland cod home range areas we observed in the winter season compared to the pre-winter seasons. Growth and metabolism of Atlantic cod fluctuate seasonally, typically declining in response to lower temperature and photoperiod in winter months (Black \& Love 1986, Foster et al. 1992, Lambert \& Dutil 1997, Levesque et al. 2005). Further increases in home range in the post-winter, may be due to increased size of individuals, in addition to increased familiarity with a larger winter home range while there is less incentive to feed. However, testing such a proposition was beyond the scope of our study.

Our results suggest an absence of intrinsic homing behaviour in individual age 1 Greenland cod. In our study, similar proportions of transplanted and control individuals left their release site during both tagging studies. Furthermore, not all dispersers travelled to the other cove. Adult Atlantic cod exhibit a negative non-linear relationship between return success and transplant distance, suggesting an important omnidirectional 'attractor' necessary to realize direction (Robichaud \& Rose 2002), or reliance on familiar landmarks (e.g. Windle \& Rose 2005). At the scale of our tagging experiments ( $3.5 \mathrm{~km}$ between coves), transplanted individuals may have been unable to perceive attractors such as habitat or abiotic cues, to orient themselves towards their site of origin (pre-release). However, the similar proportions of control and transplant disperser fish we observed suggest that the age
1 cohort may simply not attach to a particular site; individuals may choose to expand their range and learn new spatial information about foraging opportunities and predator risks before committing to a more defined home range. This argument is strengthened by the fact that most transplanted fish we observed returning to their cove of origin continued to disperse farther, suggesting no strong fidelity to the 2 capture sites per se. Moreover, the extended home ranges observed in some individuals during winter and postwinter seasons further suggest low site fidelity in our tagged populations.

There are 2 primary reasons why tag detections might have declined over each of our 2 study years: mortality or emigration. First, a crude estimate of natural mortality can be inferred from cumulative distributions of individual tracking periods in both experiments. In general, $50 \%$ of the fish spanned tracking periods greater than 4 to $5 \mathrm{mo}$, but by 6 to 7 mo only 25 to $35 \%$ of fish were still detected. This decline in tag detections is consistent with estimates of mortality for age 1 Greenland cod at our study site (up to $1 \%$ daily in smaller individuals than those we tagged; Sheppard 2005). Second, it is also possible that tagged individuals could have emigrated from our study area and were not detected doing so. However, an examination of the last detections of all tagged fish indicated that only 4 fish (1 in Year 1, 3 in Year 2) were last detected at either of the 2 most easterly of our receivers. Furthermore, additional receivers were deployed $<15 \mathrm{~km}$ from our study area, as part of another unrelated concurrent investigation. These additional receivers were arrayed in a line across Newman Sound but detected only one fish tagged during our study on 14 October 2012 , i.e. 5 mo after it was last detected by any of our receivers (J. Brattey pers. comm.). Thus, individuals are clearly capable of emigrating out of the study area, but evidence suggests that few $(\sim 5 \%$ of all the tagged fish) were detected while doing so.

Our study reveals kilometre-scale dispersal distances and home ranges for age 1 juvenile Greenland cod, indicating a higher contribution of early juvenile stages to population connectivity than earlier presumed. Atlantic cod coexist with Greenland cod in coastal Newfoundland as juveniles, allowing us to infer the dispersal potential of one species based on knowledge about the other species. Adult Greenland cod are often described as comparatively sedentary and more 'coastal' than their well-studied sibling species, the Atlantic cod. However, our results indicate an absence of homing, and that juvenile Greenland cod use larger areas than expected, particularly in winter and post-winter seasons. Therefore, juve- 
nile Atlantic cod in the area could use equal, if not larger areas than we report here, and may not exhibit strong homing behaviours at this life stage either. Correspondingly, reserves to protect nursery areas for cod will likely require larger areas than previously assumed in order to ensure appropriate protection for cod. Individual fish size and ambient seawater temperature likely drive changes in seasonal home range area. Movements associated with changing temperature regimes, such as the movements to deeper water and increased home range with season in concert with resident and disperser behaviour, all have ramifications for successful population protection and fisheries management strategies.

Acknowledgements. We thank the combined field crew from Fisheries \& Oceans Canada (DFO) and Memorial University of Newfoundland (MUN) at our Newman Sound field site-Kate Dalley, Brianna Newton, Phil Sargent, Dustin Schornagel-for all their efforts to deploy and retrieve hydrophones and capture and tag fish. We also thank David Cote (Parks Canada, Terra Nova National Park) for his advice early in the study and his technical support. We also thank Neil Ollerhead (DFO) for his GIS expertise, and Ian Fleming (MUN), Isabelle Coté, and John Brattey for advice and comments on an early version of the manuscript. This project was financially supported by a Natural Sciences and Engineering Research Council (NSERC) Canadian Graduate Scholarship and a MUN School of Graduate Studies Fellowship to M.S., and project funds from the NSERC Canadian Healthy Oceans Network ( $\mathrm{CHONe}$ ) and the DFO Centre of Expertise for Aquatic Habitat Research. Additional logistical support (vehicles, boats, accommodations and personnel) were kindly provided throughout the project by DFO, MUN, and Parks Canada.

\section{LITERATURE CITED}

Alós J, March D, Palmer M, Grau A, Morales-Nin B (2011) Spatial and temporal patterns in Serranus cabrilla habitat use in the NW Mediterranean revealed by acoustic telemetry. Mar Ecol Prog Ser 427:173-186

> Anderson JT, Gregory RS (2000) Factors regulating survival of northern cod (NAFO 2J3KL) during their first 3 years of life. ICES J Mar Sci 57:349-359

> Armstrong JD, Braithwaite VA, Huntingford FA (1997) Spatial strategies of wild Atlantic salmon parr-exploration and settlement in unfamiliar areas. J Anim Ecol 66:203-211

> Bishop MA, Reynolds BF, Powers SP (2010) An in situ, individual-based approach to quantify connectivity of marine fish: ontogenetic movements and residency of lingcod. PLoS ONE 5:e14267

Black D, Love RM (1986) The sequential mobilization and restoration of energy reserves in tissues of Atlantic cod during starving and refeeding. J Comp Physiol B 156: 469-479

Bogstad B, Lilly GR, Mehl S, Póson OK, Stefansson G (1994) Cannibalism and year-class strength in Atlantic cod (Gadus morhua L.) in arcto-boreal ecosystems (Barents Sea, Iceland, and eastern Newfoundland). ICES Mar Sci Symp 198:576-599

Börger L, Dalziel BD, Fryxell JM (2008) Are there general mechanisms of animal home range behaviour? A review and prospects for future research. Ecol Lett 11:637-650 - Bradbury IR, Laurel BJ, Robichaud D, Rose GA and others (2008) Discrete spatial dynamics in a marine broadcast spawner: re-evaluating scales of connectivity and habitat associations in Atlantic cod (Gadus morhua L.) in coastal Newfoundland. Fish Res 91:299-309

Bradford MJ, Taylor GC (1997) Individual variation in dispersal behaviour of newly emerged Chinook salmon (Oncorhynchus tshawytscha) from the Upper Fraser River, British Columbia. Can J Fish Aquat Sci 55:1585-1592

Brown C (2003) Habitat-predator association and avoidance in rainbowfish (Melanotaenia spp.). Ecol Freshw Fish 12: 118-126

Burt WH (1943) Territoriality and home range concepts as applied to mammals. J Mammal 24:346-352

Calenge C (2006) The package adehabitat for the R software: a tool for the analysis of space and habitat use by animals. Ecol Model 197:516-519

Clark DS, Green JM (1990) Activity and movement patterns of juvenile Atlantic cod, Gadus morhua, in Conception Bay, Newfoundland, as determined by sonic telemetry. Can J Zool 68:1434-1442

Colbourne EB (2004) Decadal changes in the ocean climate in Newfoundland and Labrador waters from the 1950s to the 1990s. J Northwest Atl Fish Sci 34:41-59

> Comeau LA, Campana SE, Chouinard GA (2002) Timing of Atlantic cod (Gadus morhua L.) seasonal migrations in the southern Gulf of St Lawrence: interannual variability and proximate control. ICES J Mar Sci 59:333-351

> Cote D, Ollerhead LMN, Scruton DA, McKinley RS (2003) Microhabitat use of juvenile Atlantic cod in a coastal area of Newfoundland determined by 2D telemetry. Mar Ecol Prog Ser 265:227-234

Cote D, Moulton S, Frampton PCB, Scruton DA, McKinley RS (2004) Habitat use and early winter movements by juvenile Atlantic cod in a coastal area of Newfoundland. J Fish Biol 64:665-679

Cote D, Gregory RS, Stewart HMJ (2008) Size-selective predation by river otter (Lontra canadensis) improve refuge properties of shallow coastal marine nursery habitats. Can J Zool 86:1324-1328

> Coulson MW, Marshall HD, Pepin P, Carr SM (2006) Mitochondrial genomics of gadine fishes: implications for taxonomy and biogeographic origins from whole-genome data sets. Genome 49:1115-1130

> Di Franco A, Gillanders BM, De Benedetto G, Pennetta A, De Leo GA, Guidetti P (2012) Dispersal patterns of coastal fish: implications for designing networks of marine protected areas. PLoS ONE 7:e31681

$>$ Dodson JJ (1988) The nature and role of learning in the orientation and migratory behavior of fishes. Environ Biol Fishes 23:161-182

> Espeland SH, Thoresen AG, Olsen EM, Stige LC, Knutsen H, Gjosaeter J, Stenseth NC (2010) Diel vertical migration patterns in juvenile cod from the Skagerrak coast. Mar Ecol Prog Ser 405:29-37

Farrugia TJ, Espinoza M, Lowe CG (2011) Abundance, habitat use and movement patterns of the shovelnose guitarfish (Rhinobatos productus) in a restored southern California estuary. Mar Freshw Res 62:648-657

Foster AR, Houlihan DF, Hall SJ, Burren LJ (1992) The effects of temperature-acclimation on protein-synthesis rates and nucleic-acid content of juvenile cod (Gadus morhua L). Can J Zool 70:2095-2102

> Goddard SV, Kao MH, Fletcher GL (1992) Antifreeze production, freeze resistance, and overwintering of juvenile 
Northern Atlantic cod (Gadus morhua). Can J Fish Aquat Sci 49:516-522

Goddard SV, Kao MH, Fletcher GL (1999) Population differences in antifreeze production cycles of juvenile Atlantic cod (Gadus morhua) reflect adaptations to overwintering environment. Can J Fish Aquat Sci 56:1991-1999

> Gotceitas V, Fraser S, Brown JA (1997) Use of eelgrass beds (Zostera marina) by juvenile Atlantic cod (Gadus morhua). Can J Fish Aquat Sci 54:1306-1319

Grant SM, Brown JA (1998a) Diel foraging cycles and interactions among juvenile Atlantic cod (Gadus morhua) at a nearshore site in Newfoundland. Can J Fish Aquat Sci 55:1307-1316

> Grant SM, Brown JA (1998b) Nearshore settlement and localized populations of Atlantic cod (Gadus morhua) in shallow coastal waters of Newfoundland. Can J Fish Aquat Sci 55:1317-1327

> Green JM, Wroblewski JS (2000) Movement patterns of Atlantic cod in Gilbert Bay, Labrador: evidence for bay residency and spawning site fidelity. J Mar Biol Assoc UK 80:1077-1085

> Halpern BS, Warner RR (2003) Matching marine reserve design to reserve objectives. Proc R Soc Lon B Biol Sci 270:1871-1878

> Hanson JM (1996) Seasonal distribution of juvenile Atlantic cod in the southern Gulf of St Lawrence. J Fish Biol 49: 1138-1152

Hoag H (2003) Atlantic cod meet icy death. Nature 422:792

Hughes RN, Blight CM (2000) Two intertidal fish species use visual association learning to track the status of food patches in a radial maze. Anim Behav 59:613-621

> Kao MH, Fletcher GL (1988) Juvenile Atlantic cod (Gadus morhua) can be more freeze resistant than adults. Can J Fish Aquat Sci 45:902-905

Kramer DL, Chapman MR (1999) Implications of fish home range size and relocation for marine reserve function. Environ Biol Fishes 55:65-79

> Lambert Y, Dutil JD (1997) Can simple condition indices be used to monitor and quantify seasonal changes in the energy reserves of cod (Gadus morhua)? Can J Fish Aquat Sci 54:104-112

> Laurel BJ, Gregory RS, Brown JA (2003) Settlement and distribution of age-0 juvenile cod, Gadus morhua and $G$. ogac, following a large-scale habitat manipulation. Mar Ecol Prog Ser 262:241-252

> Laurel BJ, Gregory RS, Brown JA, Hancock JK, Schneider DC (2004) Behavioural consequences of density-dependent habitat use in juvenile cod Gadus morhua and G. ogac: the role of movement and aggregation. Mar Ecol Prog Ser 272:257-270

> Levesque HM, Short C, Moon TW, Ballantyne JS, Driedzic WR (2005) Effects of seasonal temperature and photoperiod on Atlantic cod (Gadus morhua). I. Morphometric parameters and metabolites. Can J Fish Aquat Sci 62: 2854-2863

> Lewis MA, Murray JD (1993) Modelling territoriality and wolf-deer interactions. Nature 366:738-740

> Lima SL, Dill LM (1990) Behavioral decisions made under the risk of predation: a review and prospectus. Can J Zool 68:619-640

> Lindholm J, Auster PJ, Knight A (2007) Site fidelity and movement of adult Atlantic cod Gadus morhua at deep boulder reefs in the western gulf of Maine, USA. Mar Ecol Prog Ser 342:239-247

Linehan JE, Gregory RS, Schneider DC (2001) Predation risk of age-0 cod (Gadus) relative to depth and substrate in coastal waters. J Exp Mar Biol Ecol 263:25-44

> March D, Palmer M, Alós J, Grau A, Cardona F (2010) Short-

Editorial responsibility: Nicholas Tolimieri,

Seattle, Washington, USA term residence, home range size, and diel patterns of the painted comber Serranus scriba in a temperate marine reserve. Mar Ecol Prog Ser 400:195-206

> Methven DA, McGowan C (1998) Distinguishing small juvenile Atlantic cod (Gadus morhua) from Greenland cod (Gadus ogac) by comparing meristic characters and discriminant function analyses of morphometric data. Can J Zool 76:1054-1062

> Miller TJ, Crowder LB, Rice JA, Marschall EA (1988) Larval size and recruitment mechanisms in fishes: toward a conceptual framework. Can J Fish Aquat Sci 45:1657-1670

Morin B, Hudon C, Whoriskey F (1991) Seasonal distribution, abundance, and life-history traits of Greenland cod, Gadus ogac, at Wemindji, eastern James Bay. Can J Zool 69:3061-3070

> Neat FC, Wright PJ, Zuur AF, Gibb IM and others (2006) Residency and depth movements of a coastal group of Atlantic cod (Gadus morhua L.). Mar Biol 148:643-654

Odling-Smee L, Braithwaite VA (2003) The influence of habitat stability on landmark use during spatial learning in the three-spined stickleback. Anim Behav 65:701-707

Paradis AR, Pepin P, Brown JA (1996) Vulnerability of fish eggs and larvae to predation: review of the influence of the relative size of prey and predator. Can J Fish Aquat Sci 53:1226-1235

Rhodes JR, McAlpine CA, Lunney D, Possingham HP (2005) A spatially explicit habitat selection model incorporating home range behaviour. Ecology 86:1199-1205

Robichaud D, Rose GA (2002) The return of cod transplanted from a spawning ground in southern Newfoundland. ICES J Mar Sci 59:1285-1293

Robichaud D, Rose GA (2004) Migratory behaviour and range in Atlantic cod: inference from a century of tagging. Fish Fish 5:185-214

Schneider DC, Norris MJ, Gregory RS (2008) Predictive analysis of scale-dependent habitat association: juvenile cod (Gadus spp.) in eastern Newfoundland. Estuar Coast Shelf Sci 79:71-78

Scott MG, Scott WB (1988) Atlantic fishes of Canada. University of Toronto Press, Toronto

Sheppard GL (2005) Natural mortality and movement of juvenile cod (Gadus spp.) inhabiting eelgrass (Zostera marina) in coastal Newfoundland waters. MSc Thesis, Memorial University of Newfoundland, St. John's

Simpfendorfer CA, Heupel MR, Hueter RS (2002) Estimation of short-term centers of activity from an array of omnidirectional hydrophones and its use in studying animal movements. Can J Fish Aquat Sci 59:23-32

Taylor EB (1990) Phenotypic correlates of life-history variation in juvenile Chinook salmon, Oncorhynchus tshawytscha. J Anim Ecol 59:455-468

> Thistle ME, Schneider DC, Gregory RS, Wells NJ (2010) Fractal measures of habitat structure: maximum densities of juvenile cod occur at intermediate eelgrass complexity. Mar Ecol Prog Ser 405:39-56

Tupper M, Boutilier RG (1995) Size and priority at settlement determine growth and competitive success of newly settled Atlantic cod. Mar Ecol Prog Ser 118:295-300

Wang M, Grimm V (2007) Home range dynamics and population regulation: an individual-based model of the common shrew Sorex araneus. Ecol Model 205:397-409

Wickham H (2011) The split-apply-combine strategy for data analysis. J Stat Softw 40:1-29

Windle MJS, Rose GA (2005) Migration route familiarity and homing of transplanted Atlantic cod (Gadus morhua). Fish Res 75:193-199

> Worton BJ (1989) Kernel methods for estimating the utilization distribution in home-range studies. Ecology 70:164-168

Submitted: October 28, 2013; Accepted: January 13, 2014

Proofs received from author(s): March 28, 2014 